\title{
Impact of Light Intensity and Nitrogen of Nutrient Solution on Nitrate Content in Three Lettuce Cultivars Prior to Harvest
}

\author{
Khurshied Ahmed Khan ${ }^{1}$, Zhengnan Yan $^{1} \&$ Dongxian $\mathrm{He}^{1}$ \\ ${ }^{1}$ College of Water Resources and Civil Engineering, China Agricultural University, Beijing, China \\ Correspondence: Dongxian He, Key Lab. of Agricultural Engineering in Structure and Environment of Ministry \\ of Agriculture, College of Water Resources and Civil Engineering, China Agricultural University, Tsinghua East \\ Rd. 17, Haidian, Beijing 100083, China. E-mail: hedx@cau.edu.cn
}

$\begin{array}{ll}\text { Received: January 24, } 2018 & \text { Accepted: April 2, } 2018 \quad \text { Online Published: May 15, } 2018 \\ \text { doi:10.5539/jas.v10n6p99 } & \text { URL: https://doi.org/10.5539/jas.v10n6p99 }\end{array}$

The research is financed by the National Key Research and Development Program of China (2017YFB0403901).

\begin{abstract}
Nitrate smoothly accumulates in leafy vegetables and poses serious health hazards if connected excessively in the human diet. The objective of this study was to improve the cultivation method of low nitrate lettuce grown in plant factory. A substantial decrease of nitrate content $\left(\mathrm{NO}_{3}{ }^{-}\right)$in three lettuce cultivars were subjected by short-term pre-harvest treatment combined with lowing nitrogen supply of nutrient solution to half concentration and high photosynthetic photon flux density (PPFD) by LED lighting. The lettuce (Lactuca sativa L. cv. Frill ice, Lvzhu, Ziwei) were hydroponically grown in full strength of nutrient solution based on Yamasaki formula up to harvest time within a controlled environment under two light sources using fluorescent lamps and LEDs. The results demonstrated that a subsequent 3-days treatment of additional PPFD from $250 \mu \mathrm{mol} \mathrm{m} \mathrm{s}^{-2}$ to $350 \mu \mathrm{mol}$ $\mathrm{m}^{-2} \mathrm{~s}^{-1}$ from 18 days after transplanting and half concentrations of nitrogen $\left(\mathrm{NO}_{3}^{-}-\mathrm{N}\right)$ in nutrient solution which is composition to standard resulted in the decrease of nitrate content as compared to plants grown under initial PPFD and full concentration of $\mathrm{NO}_{3}^{-}-\mathrm{N}$ composition. The gradual decrease in nitrate content was accompanied by an increased concentration of nutritionally carbohydrates. Another important indicator of nutritional quality such as vitamin $\mathrm{C}$ content exhibited some variation, fresh weight of cultivars in cv. Frill ice and Ziwei observed higher with fluorescent lamps and for cv. Lvzhu with LED treatment section followed by lowest nitrate content of fresh leaves, respectively. Further, presented results disclosed that to avoid high accumulation of nitrate in leafy vegetables, the strategy of lowering nitrogen supply and increasing light intensity prior to harvest benefiting growers and consumers by improving quality of the product also making it consumer friendly.
\end{abstract}

Keywords: LED lighting, nitrate reduction, quality attributes, plant factory, photosynthetic photon flux density

\section{Introduction}

Leafy vegetables are rich in nutritional values, including phytochemicals, minerals, and vitamins, but an essential nutritional quality factor of vegetables is low nitrate content (Ryszard et al., 2017). Therefore, to sustain health, ingestion of vegetables is required as a supplement to human nutrition and its regular consumption in daily intake is effective host defense against chronic diseases (Qiu et al., 2014; Mircea et al., 2015). Unfortunately, leafy vegetables especially grown in hydroponics accumulate higher levels of nitrate and other harmful substances and its threatening compounds nitrites are involved in methemoglobinemia (Hung et al., 2004; Catherine et al., 2017) which causes a lack of oxygen in the tissues and risk of developing stomach cancer (Santamaria, 2006; Shohreh \& Leila, 2015). The excessive injection of nitrate in dietary intake is restrictive according to food authorities (Abd-Elkader et al., 2016).

With regard to nitrate content and its effects on human health have established to the adoption of law by the European Union acceptable limit for lettuce (2500-4500 mg Kg${ }^{-1}$ in fresh weight) respectively depending on cultivation modes (Du et al., 2007; Santiago et al., 2008; Liu et al., 2014). Leafy vegetables have the ability to accumulate a higher level of nitrate in leaves during growth (Yeh \& Chung, 2009). The nitrate content of leaves increases significantly when plants exposed to lower light intensities and excessive nitrogen fertilization that leads to imbalance absorption between uptake and reduction of nitrate ions which results in higher nitrate 
accumulation. Nitrogen concentration in rhizosphere and light intensity are identified as the most important environmental factors to influence nitrate content in vegetable production under controlled environment (Baslam et al., 2011; Cometti et al., 2011).

Nitrogen concentration in the rhizosphere is primary essential element required for successful plant growth and also involved in plant metabolism as a constituent of protein and secondary metabolites (Brady \& Weil, 2008; Liu et al., 2016). Therefore, an excessive amount of nitrogenous fertilizers practiced to crops in consideration of high yield (Li et al., 2009; Francisco et al., 2017). However, when injection of nitrogen exceeds the demand, plants not capable to absorb it, several studies have reported that a high nitrate accumulation in plants proceeds in nitrite production which is harmful to plant growth as well to human health. Therefore, nitrate accumulation in leafy vegetables under the hydroponic system is directly dependent the compositional amount of nitrogen fertilizer (Chen et al., 2014).

In addition, light intensity also modulates uptake and nitrate reduction and considered as the leading influential factors that control nitrate accumulation in vegetable leaves (Lillo, 1994; Santamaria, 2006; Rivas-Ubach et al., 2012; Albornoz \& Lieth, 2015). It's reported that plants accumulate more nitrate under low light intensities especially in dark period (Lillo, 2004). For instance, light intensity strengthens the photosynthetic activity, and magnify the source level of nitrate assimilation materials, including reductants, energy and carbon skeleton (Zhou et al., 2013) and that plays a significant role to drive biochemical activity (Bian et al., 2015; Chen et al., 2017). This balance can be disrupted under low light intensity, so that roots will take up $\mathrm{NO}_{3}{ }^{-}-\mathrm{N}$ faster than the plant convert the $\mathrm{NO}_{3}{ }^{-} \mathrm{N}$ to proteins. Previous studies highlighted following culture measures to avoid nitrate accumulation in lettuce by nitrogen fertilization including pre-harvest nitrogen-reduced solutions (Demsar et al., 2004; Ombodi et al., 2010; Albornoz et al., 2014). Specifying the nitrogen supply in solution with growth stages (McCall \& Willumsen, 1999; Seginer, 2003) is another strategy reported in literatures. The use of nitrogen free solution before harvest has significant effect on nitrate content of leafy vegetables (Izmailov, 2004; Yan et al., 2014; Shohreh \& Leila, 2015). Many authors have suggested that additions and partial replacing and balancing nitrate ions with chloride before crop maturity (Gunes et al., 2004; Pavlos et al., 2014) affects nitrate content. The control of environmental factors with respect to nitrate accumulation (Gruda, 2005; Wang et al., 2008; Hall et al., 2015) and predicting and manipulating nitrate deficiency in relation to other fertilization chemicals (Ahmed et al., 2000; Burns et al., 2011) have resulted in substantial decrease in nitrate content. Nitrate accumulation can also be strained by using different forms of nitrogen bio-fertilizers which also have positive effects and reduce $\mathrm{NO}_{3}{ }^{-} \mathrm{N}$ accumulation (Mircea et al., 2015). In protected horticulture, an effective strategy to reduce nitrate is to withhold nitrogen before harvest (Santamaria et al., 2001; Siti Fairuz et al., 2015). It is reported in several studies that stopping the nitrogen supply in growth medium few days before crop maturity, reduces the nitrate content. In addition, red and blue wavelengths in light spectrum effectively reduce nitrate contents.

Lettuce used as salad is most popular in leafy vegetable. However, there is little information on how interactive effects of light intensity and nitrogen application efficiencies levels before harvest to influence the $\mathrm{NO}_{3}{ }^{-} \mathrm{N}$ in leaves of lettuce cultivars in protected horticulture. The results of this study aim to lettuce quality control with low nitrate content in plant factory and greenhouse industry for safe human consumption.

\section{Materials and Methods}

The current investigation was undertaken in plant factory (College of Water Resources and Civil Engineering, China Agricultural University in Beijing) to evaluate the impacts of light intensity and nitrogen supply of nutrient solution before harvest on morphological, physiological, and quality attributes of hydroponic lettuce.

\subsection{Plant Material and Growth Conditions}

Seeds of three cultivars of lettuce (Lactuca sativa L. cv. Frill ice, Lvzhu, Ziwei) were used as plant materials. Germinated seedling of the five-leaf stage was transplanted to the hydroponic system on acrylonitrile butadiene styrene (ABS) cultivation board (length $120 \mathrm{~cm} \times$ width $90 \mathrm{~cm} \times$ height $7 \mathrm{~cm}$ ) in the plant factory. Each complete board contained 24 plants spaced $20 \mathrm{~cm}$ apart. The growth conditions were monitored by the environmental control system. The plants were exposed to temperature, $\mathrm{CO}_{2}$ concentration, and relative humidity each at $24 \pm 1{ }^{\circ} \mathrm{C} / 20 \pm 1{ }^{\circ} \mathrm{C}$ (light/dark), $800 \pm 50 \mu \mathrm{mol} \mathrm{mol}^{-1}$, and $70 \pm 5 \% / 65 \pm 10 \%$ (light/dark), respectively. The lettuce plants were irradiated with T5 fluorescent lamps (R:B ratio of 1.8) and LED lamps (R:B ratio of 1:2) at a photoperiod of $16 \mathrm{~h} \mathrm{~d}^{-1}$ and photosynthetic photon flux density (PPFD) of $250 \mu \mathrm{mol} \mathrm{m} \mathrm{m}^{-2} \mathrm{~s}^{-1}$ to mounted transplant on the cultivation board. The nutrient solution used to culture all varieties was based on full standard solution based on Japanese Yamasaki lettuce formula. 
The Yamasaki lettuce solution was utilized with major nutrient elements of $\mathrm{N}, \mathrm{P}, \mathrm{K}, \mathrm{Ca}$, and $\mathrm{Mg}$ at 91.0, 15.5, 136.4, 40.0, and $12.2 \mathrm{mg} \mathrm{L}^{-1}$, and the standard content of minor elements solution with (mg L $\left.\mathrm{m}^{-1}\right) 3.54 \mathrm{Fe}, 0.52$ $\mathrm{Mn}, 0.05 \mathrm{Zn}, 0.02 \mathrm{Cu}, 0.50 \mathrm{P}$, and $0.01 \mathrm{Mo}$. The nutrient solution was renewed after 10 days and adjusted to electrical conductivity in $1.0-1.2 \mathrm{~ms} \mathrm{~cm}^{-1}$ and $\mathrm{pH}$ in $6.0-6.5$ daily. The light intensity adjusted to $250 \mu \mathrm{mol} \mathrm{m} \mathrm{m}^{-2}$ at distance of $15 \mathrm{~cm}$ from the light source with a digital photometer (LI-250A, LI-COR Inc., Lincoln, NE, USA) to support proper growth and development of lettuce plants. Before the quality control treatments, six plants from each variety were sampled. The nitrate content was recorded. The remaining plants from each variety were subjected to another 3-days treatment with the various level of nitrogen concentration of the nutrient solution as follows in P250-SF, P250-SH, and P350-SH. The experimental zone named P350-SH received additionally light intensity from $250 \mu \mathrm{mol} \mathrm{m} \mathrm{s}^{-2}$ to $350 \mu \mathrm{mol} \mathrm{m} \mathrm{m}^{-2} \mathrm{~s}^{-1}$ in each treatment group. The detailed description of quality control treatments is given in Table 1 .

Table 1. Description of quality control treatments for lettuce cultivated under artificial lighting

\begin{tabular}{llll}
\hline Light source & $\begin{array}{l}\text { Photosynthetic photon flux } \\
\text { density prior to harvest } \\
\left(\mu \mathrm{mol} \mathrm{m} \mathrm{s}^{-2}\right)\end{array}$ & $\begin{array}{l}\text { Solution supply in } \\
\text { standard concentration } \\
\text { prior to harvest }\end{array}$ & Treatments symbol \\
\hline Fluorescent lamp with R:B ratio of 1.8 & 250 & Full conc. & F1.8-P250-SF \\
& 250 & Half conc. & F1.8-P250-SH \\
& 350 & Half conc. & F1.8-P350-SH \\
LED lamp with R:B ratio of 1.2 & 250 & Full conc. & L1.2-P250-SF \\
& 250 & Half conc. & L1.2-P250-SH \\
& 350 & Half conc. & L1.2-P350-SH \\
\hline
\end{tabular}

\subsection{Plant Sampling and Growth Analysis}

Plants were separated into leave and roots respectively in each variety after removing the entire plant from the trough during the harvesting time and data recorded on plant leaves length, width, number of leaves, fresh leaves and roots were weighed separately and then oven-dried to constant weights, respectively.

The chlorophyll determined in $80 \%$ acetone extracted leaves at absorbance measured at wavelengths of $663 \mathrm{~nm}$ and $645 \mathrm{~nm}$ by using a spectrophotometer (UV-3150, Shimadzu Productions Co., Japan). The photosynthetic parameters were determined by using a portable photosynthesis system (LI-6400XT, LI-COR Inc., Lincoln, NE, USA).

\subsection{Determination of Quality Attributes}

Six lettuce plants were randomly sampled for determination of initial value from the three lettuce cultivars at the beginning and end of 3 days treatment. Samples for determination of nitrate contents and quality attributes were measured by standard described methods in the literature. Nitrate contents of fresh sampled leaves were measured by the sulfosalicylic acid method. Fresh samples were cut up and mixed carefully, then 2-3 g of pieces was placed into $10-\mathrm{mL}$ tubes of distilled water, after being boiled in a water-bath for $30 \mathrm{~min}$, the extract was filtered and diluted with distilled water to $50 \mathrm{~mL}$. Nitrate contents were determined using the method described by Liu et al. (2016). A $0.1 \mathrm{~mL}$ extract was sampled and mixed thoroughly with $0.4 \mathrm{~mL}$ of $5 \%$ (w/v) salicylic acid in concentrated sulfuric acid $\left(\mathrm{H}_{2} \mathrm{SO}_{4}\right)$, after the acidic mixture had been kept for 20 min at room temperature, 9.5 $\mathrm{mL}$ of $8 \%$ sodium hydroxide $(\mathrm{NaOH})$ was added slowly to raise the $\mathrm{pH}$, then the absorbance at $410 \mathrm{~nm}$ was determined by above spectrophotometry for identification of nitrate level.

Soluble sugar content determined by Anthrone colorimetry method by using above spectrophotometer at the wavelength of $630 \mathrm{~nm}$. Vitamin C content identifies by 2,6-dichlorophenol indophenol titration procedure. Soluble protein content was analyzed by Coomassie brilliant blue G-250 staining at $595 \mathrm{~nm}$ wavelength by using above spectrophotometer. Mineral ions composition such as potassium and phosphorus were measured by using atomic absorption spectrophotometer (AA7002, Beijing East and West Electronic Instrument Co., Ltd., Beijing) and above spectrophotometer.

\subsection{Statistical Analysis}

All experimental data were subjected and analyzed using Microsoft Excel 2010, and statistical software SPSS. ANOVA, LSD and Duncan multiple range test were performed to determine the significant difference $(\mathrm{p}<0.05)$ between treatments. 


\section{Results and Discussion}

The present study observed the influences of higher light intensity and low nitrogen supply for regulation of pre-harvest quality management in three types of lettuce.

\subsection{Interaction Impact of Nitrogen Supply and Light Intensity on Nitrate Content and Quality Attributes of Hydroponic Lettuce}

The interaction term in nitrogen supply and light intensity had significant influence for nitrate content of lettuce leaves in each variety irrespective of light sources (Figure 1). The data depicted that lettuce plants supplied with the full nitrogen composition in solution had the highest leaf nitrate content and that was much lower in plants treated with under taken together supplementary higher lighting and withholding half nitrogen supply of nutrient solution.

The data regarding nitrate content in lettuce cultivar's in response to pre-harvest treatment depicted that changes of nitrate content in lettuce are significant difference after treatment break, the minimum nitrate content in variety cv. Frill ice $\left(1023 \pm 254 \mathrm{mg} \mathrm{Kg}^{-1}\right)$ were obtained in case of F1.8-P350-SH under fluorescent lamps, whereas in cv. Lvzhu with the lowest nitrate content $\left(545 \pm 126 \mathrm{mg} \mathrm{Kg}^{-1}\right)$ after treatment break was observed under LEDs (L1.2-P350-SH). Likewise, the lowest nitrate content in cv. Ziwei $\left(392 \pm 73 \mathrm{mg} \mathrm{Kg}^{-1}\right)$ was obtained in treatment L1.2-P350-SH. It's also worth noting that leaf tissue nitrate found in higher contents under the LED lighting with the full strength of nutrient solution, but it gradually decreases with increasing light intensity with half nitrogen supply of nutrient solution.

It is well known that light intensity and nitrogen fertilization influence the nitrate uptake from root zone and its assimilation in plants (Makus et al., 2002). The data showed that nitrate content of lettuce varieties also dependent on these two factors due to fact that higher light intensity provides more carbohydrates (Zhou et al., 2013) and phytochemical (Liu et al., 2016) to nitrate assimilation to amino acids (Konstantopoulou et al., 2010). Further nitrogen level in growth medium also plays a crucial role in the nitrate accumulation of leafy vegetables (Stagnari et al., 2015). The accelerating effects of increased PPFD and half nitrogen supply indicates the reason for nitrate decrease in leaf tissue of lettuce regardless of cultivar.

The changes in nitrate level and elevated sucrose content was supported by an increased net photosynthetic rate. It's in agreement with the idea that limiting the nitrogen level of nutrient solution significantly reduces the input of nitrate towards the osmotic potential (McCall \& Willumsen, 1999) and increases that glucose and sucrose (Shen, 2016). Furthermore, an input of nitrate to the osmotic potential becomes partially get low and that of sugar significantly enhanced (Lillo, 2004). Therefore, the higher soluble sugar content in treatments receiving half nitrogen supply with supplementation of light which may be the key factor nitrate during the cultivation process that leads to declining of accumulated nitrate in different lettuce cultivars.

From results, it can be inferred that after 18 days of transplanting, samples of nitrate analysis among lettuce cultivars showed different nitrate accumulation level in leaf tissues, this depicted that uptake and transport of nitrogen are affected by light quality, cultivar choice, and solution composition. It is revealed in previous studies that total reduced nitrogen content is coupled with photosynthesis which determines the synthesis of proteins and amino acids in cellular components (Cometti et al., 2011). These results are consistent with the previous findings that in the light quality has a greater influence on the activity of nitrate reductase by photosynthesis (Lillo \& Appenroth, 2001).

Taken together the combination of lowering the nitrogen supply of nutrient solution and increasing the light intensity seemed also effective in stimulating of other important functional nutrients, such as $\mathrm{K}$, vitamin $\mathrm{C}$, and protein as shown in Table 2. These nutritional compounds in lettuce types significantly respond to above phenomena. The highest vitamin $\mathrm{C}$ and lowest potassium contents were obtained in treatment $\mathrm{P} 350$-SH for each variety. The reason of high vitamin $\mathrm{C}$ content in treatment with lower nitrogen supply and higher light intensity is that it has been already found that light intensity and nitrogen supply are the main factors for controlling regulation of vitamin C in leafy vegetables (Lester, 2006; Lee \& Kader, 2000). Reduction in light intensity would result in decline in vitamin C content (Makus \& Lester, 2002) and increased nitrogen was found to decrease vitamin C content in various horticultural crops (Lee \& Kader, 2000). 

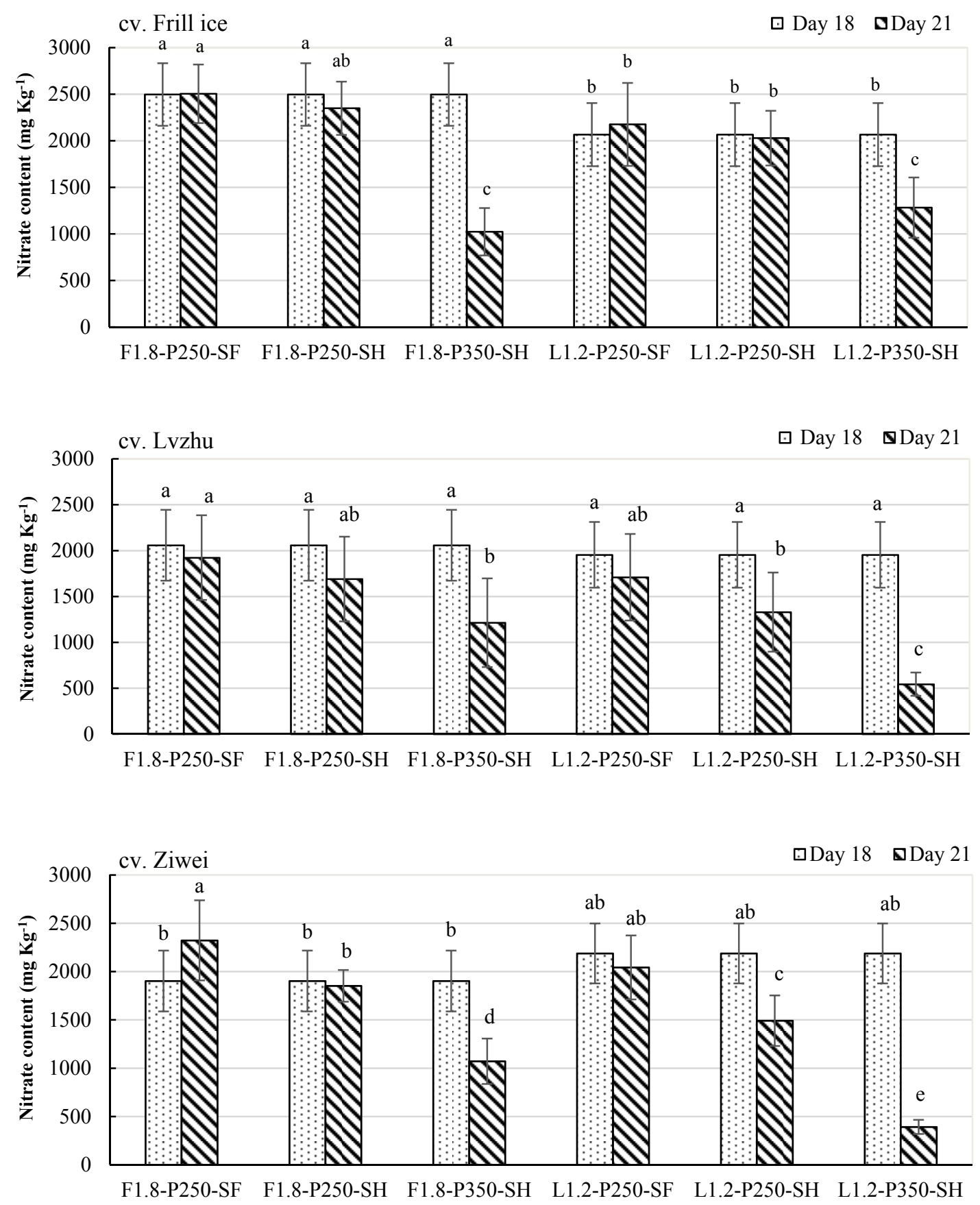

Figure 1. Effects of light environment and nitrogen supply prior to harvest on initial and terminal nitrate contents in three types of lettuce (cv. Frill ice, Lvzhu, Ziwei) 
Table 2. Interactive effects of combination of light intensity and nitrogen supply prior to harvest on quality attributes of lettuces in three cultivars at harvest. The alphabetic letters show significant difference at $\mathrm{P}<0.05$ by LSD

\begin{tabular}{|c|c|c|c|c|c|c|}
\hline Lettuce cultivar & Treatment & $\begin{array}{l}\text { Soluble sugar } \\
\text { content }\end{array}$ & $\begin{array}{l}\text { Vitamin } \mathrm{C} \\
\text { content }\end{array}$ & $\begin{array}{l}\text { Soluble protein } \\
\text { content }\end{array}$ & $\begin{array}{l}\text { Phosphorus } \\
\text { content }\end{array}$ & $\begin{array}{l}\text { Potassium } \\
\text { content }\end{array}$ \\
\hline \multirow{7}{*}{ cv. Frill ice } & & ----- \% ------ & -- mg $100 \mathrm{~g}^{-1}--$ & ------ $\mathrm{mg} \mathrm{g}^{-1}$----- & ---- $\mathrm{mg} \mathrm{g}^{-1}$---- & ----- \% ------ \\
\hline & F1.8-P250-SF & $0.60 \pm 0.34 \mathrm{~b}$ & $16.64 \pm 2.03 \mathrm{c}$ & $5.62 \pm 1.08 \mathrm{~b}$ & $4.42 \pm 0.24 \mathrm{~b}$ & $6.56 \pm 1.20 \mathrm{a}$ \\
\hline & F1.8-P250-SH & $0.53 \pm 0.20 \mathrm{~b}$ & $12.90 \pm 2.70 \mathrm{~d}$ & $6.74 \pm 2.30 \mathrm{a}$ & $2.95 \pm 1.30 \mathrm{c}$ & $5.74 \pm 0.90 \mathrm{ab}$ \\
\hline & F1.8-P350-SH & $1.09 \pm 0.35 \mathrm{a}$ & $16.35 \pm 3.04 \mathrm{c}$ & $6.48 \pm 1.08 \mathrm{ab}$ & $2.88 \pm 1.29 \mathrm{c}$ & $5.30 \pm 0.50 \mathrm{~b}$ \\
\hline & L1.2-P250-SF & $0.59 \pm 0.12 b$ & $23.24 \pm 3.10 \mathrm{~b}$ & $4.30 \pm 0.73 \mathrm{c}$ & $6.39 \pm 1.21 \mathrm{a}$ & $5.47 \pm 0.69 \mathrm{~b}$ \\
\hline & L1.2-P250-SH & $0.62 \pm 0.22 \mathrm{~b}$ & $20.47 \pm 4.83 \mathrm{bc}$ & $4.89 \pm 1.37 \mathrm{c}$ & $6.06 \pm 0.32 \mathrm{a}$ & $5.09 \pm 0.65 \mathrm{~b}$ \\
\hline & L1.2-P350-SH & $1.22 \pm 0.37 \mathrm{a}$ & $29.98 \pm 6.28 \mathrm{a}$ & $4.88 \pm 1.77 \mathrm{c}$ & $3.98 \pm 0.54 \mathrm{~b}$ & $3.88 \pm 0.49 \mathrm{c}$ \\
\hline \multirow[t]{6}{*}{ cv. Lvzhu } & F1.8-P250-SF & $0.58 \pm 0.18 \mathrm{~b}$ & $31.19 \pm 3.54 \mathrm{a}$ & $6.05 \pm 0.64 \mathrm{NS}$ & $5.57 \pm 1.37 \mathrm{a}$ & $5.48 \pm 0.46 \mathrm{~b}$ \\
\hline & F1.8-P250-SH & $0.48 \pm 0.17 \mathrm{bc}$ & $29.17 \pm 4.70 \mathrm{ab}$ & $5.54 \pm 1.31 \mathrm{NS}$ & $4.59 \pm 0.79 \mathrm{ab}$ & $4.24 \pm 0.89 \mathrm{c}$ \\
\hline & F1.8-P350-SH & $0.61 \pm 0.17 \mathrm{~b}$ & $37.62 \pm 4.35 \mathrm{a}$ & $5.26 \pm 1.57 \mathrm{NS}$ & $3.95 \pm 1.17 \mathrm{~b}$ & $3.80 \pm 1.17 \mathrm{c}$ \\
\hline & L1.2-P250-SF & $0.41 \pm 0.23 \mathrm{bc}$ & $19.94 \pm 5.87 \mathrm{~b}$ & $5.08 \pm 0.76 \mathrm{NS}$ & $4.69 \pm 0.55 \mathrm{ab}$ & $6.75 \pm 0.47 \mathrm{a}$ \\
\hline & L1.2-P250-SH & $0.30 \pm 0.09 \mathrm{c}$ & $20.65 \pm 6.64 \mathrm{~b}$ & $5.27 \pm 0.42 \mathrm{NS}$ & $4.24 \pm 0.70 \mathrm{ab}$ & $5.83 \pm 0.58 \mathrm{ab}$ \\
\hline & L1.2-P350-SH & $1.05 \pm 0.36 \mathrm{a}$ & $33.96 \pm 8.13 \mathrm{a}$ & $5.47 \pm 0.83 \mathrm{NS}$ & $3.42 \pm 1.10 \mathrm{~b}$ & $4.43 \pm 0.98 \mathrm{c}$ \\
\hline \multirow[t]{6}{*}{ cv. Ziwei } & F1.8-P250-SF & $0.54 \pm 0.25 \mathrm{c}$ & $20.67 \pm 6.78 \mathrm{a}$ & $5.70 \pm 1.12 \mathrm{a}$ & $5.39 \pm 0.46 \mathrm{bc}$ & $6.52 \pm 1.79 \mathrm{a}$ \\
\hline & F1.8-P250-SH & $0.47 \pm 0.08 \mathrm{c}$ & $18.00 \pm 4.09 \mathrm{~b}$ & $4.87 \pm 1.59 \mathrm{ab}$ & $4.20 \pm 0.98 \mathrm{c}$ & $4.84 \pm 1.11 b$ \\
\hline & F1.8-P350-SH & $1.39 \pm 0.43 \mathrm{a}$ & $24.05 \pm 5.19 \mathrm{a}$ & $6.11 \pm 1.94 \mathrm{a}$ & $4.23 \pm 0.65 \mathrm{c}$ & $4.03 \pm 0.88 \mathrm{~b}$ \\
\hline & $\mathrm{L} 1.2-\mathrm{P} 250-\mathrm{SF}$ & $0.85 \pm 0.21 \mathrm{~b}$ & $22.26 \pm 2.74 \mathrm{a}$ & $4.57 \pm 1.47 \mathrm{ab}$ & $8.67 \pm 1.16 \mathrm{a}$ & $4.61 \pm 0.68 \mathrm{~b}$ \\
\hline & L1.2-P250-SH & $0.81 \pm 0.33 b$ & $18.65 \pm 4.17 b$ & $4.08 \pm 0.38 \mathrm{~b}$ & $6.08 \pm 2.19 \mathrm{~b}$ & $4.78 \pm 0.51 \mathrm{~b}$ \\
\hline & L1.2-P350-SH & $1.34 \pm 0.48 \mathrm{a}$ & $23.61 \pm 2.11 \mathrm{a}$ & $5.84 \pm 0.72 \mathrm{a}$ & $5.74 \pm 1.27 \mathrm{~b}$ & $3.79 \pm 1.41 \mathrm{~b}$ \\
\hline
\end{tabular}

3.2 Interactive Impact of Lowing Nitrogen Supply and Increased Light Intensity on Morphological and Physiological Attributes of Lettuces

Morphological and physiological attributes of the three lettuce cultivars were subjected to different treatments, fresh weight and dry weight of leaves as shown in Table 3 for lettuce variety (cv. Frill ice and Ziwei) were found in $108.3,97.7 \mathrm{~g} \mathrm{plant}^{-1}$, and 4.40, $3.05 \mathrm{~g} \mathrm{plant}^{-1}$, respectively, under fluorescent lamps at treatment of F1.8-P350-SH. While cv. Lvzhu lettuce showed maximum fresh weight of leaves (118.2 $\left.\mathrm{g} \mathrm{plant}^{-1}\right)$ in treatment of F1.8-P250-SF.

All lettuce cultivar's exhibited variation in leaves fresh weight by the end of three days treatment under different conditions of nitrogen supply and light intensity. The fresh weight and photosynthetic characteristics were significantly higher in plants treated with half concentration of main composition of nutrient solution and high light intensity. The results supported the view that half concentration of nutrient solution is effective in plant growth prior to harvest. This is due to the fact that higher nitrogen supply causes photo-oxidative damage which results in photosynthetic inhibition due to an imbalance between carbon-nitrogen ratios (Martinez-Luscher et al., 2015; Gartner, 2017). The finding of this study is in the line with that excessive main solution composition did not bring maximum plant growth (Zhou et al., 2013; Hogewoning et al., 2010; Hernandez \& Kubota, 2016). Moreover, our study suggests that optimum nitrogen supply and short-term increased light intensity could stimulate plant growth because lettuce cultivars fix more amount of carbon in photosynthetic process during receiving half nitrogen composition and high light intensity and that appeared obvious in treatment of F1.8-P350-SH. However, plants showed faster growth and substantial productivity after exposing them to half nitrogen for 3 days with high light intensity. Based on above results, this finding suggests that light and nitrogen are primary factors which provide optimal plant production driven by photosynthesis.

Although the data regarding physiological parameters showed that genetics and environmental seemed factors responsible for regulation of morphogenesis and development of lettuce varieties (Aldesuquy et al., 2000). The growth parameters result clarified that the light quality had a significant effect on morphological characteristics (fresh weight and dry weight) in three types of lettuce. The data depicted that lettuce cultivars responded to a same environmental condition but under different light qualities in a different way to gain productivity and 
quality attributes. The initial obtained results of morphological and quality attributes are in line with previous findings reported by Borowski et al. (2014). Light spectrum especially red and blue lights act as abiotic signal that stimulates and regulate the morphogenesis and development and shapes the morphology of plants (Perez et al., 2015).

Table 3. Interactive impact of lowing nitrogen supply and increased light intensity on morphological and physiological attributes of hydroponic lettuces

\begin{tabular}{|c|c|c|c|c|c|c|}
\hline Lettuce cultivar & Treatment & $\begin{array}{l}\text { Net photosynthetic } \\
\text { rate }\end{array}$ & $\begin{array}{l}\text { Transpiration } \\
\text { rate }\end{array}$ & $\begin{array}{l}\text { Total chlorophyll } \\
\text { content }\end{array}$ & $\begin{array}{l}\text { Fresh weight } \\
\text { of leaves }\end{array}$ & $\begin{array}{l}\text { Dry weight } \\
\text { of leaves }\end{array}$ \\
\hline \multirow{7}{*}{ cv. Frill ice } & & $---\mu \mathrm{mol} \mathrm{m} \mathrm{m}^{-2} \mathrm{~s}^{-1}$ & $-\mathrm{mmol} \mathrm{m} \mathrm{m}^{-2} \mathrm{~s}^{-1}-$ & ----- $\mathrm{mg} \mathrm{g}^{-1}$ & --- g plant $^{-1}$--- & --- g plant ${ }^{-1}$--- \\
\hline & F1.8-P250-SF & $6.0 \pm 2.3 \mathrm{~b}$ & $0.78 \pm 0.30 \mathrm{ab}$ & $1.16 \pm 0.23 \mathrm{NS}$ & $106.8 \pm 19.7 \mathrm{a}$ & $4.14 \pm 0.72 \mathrm{a}$ \\
\hline & F1.8-P250-SH & $7.5 \pm 1.9 \mathrm{ab}$ & $0.93 \pm 0.12 \mathrm{a}$ & $1.31 \pm 0.17 \mathrm{NS}$ & $106.4 \pm 25.3 \mathrm{a}$ & $4.50 \pm 0.69 \mathrm{a}$ \\
\hline & F1.8-P350-SH & $9.7 \pm 2.4 \mathrm{a}$ & $0.42 \pm 0.19 \mathrm{c}$ & $1.15 \pm 0.08 \mathrm{NS}$ & $108.3 \pm 19.0 \mathrm{a}$ & $4.40 \pm 0.81 \mathrm{a}$ \\
\hline & L1.2-P250-SF & $5.6 \pm 1.2 \mathrm{c}$ & $0.58 \pm 0.16 \mathrm{~b}$ & $1.37 \pm 0.37 \mathrm{NS}$ & $85.8 \pm 4.4 \mathrm{~b}$ & $3.15 \pm 0.38 \mathrm{~b}$ \\
\hline & L1.2-P250-SH & $5.7 \pm 1.7 \mathrm{c}$ & $0.51 \pm 0.24 \mathrm{bc}$ & $1.40 \pm 0.18 \mathrm{NS}$ & $78.6 \pm 7.5 \mathrm{c}$ & $2.95 \pm 0.29 \mathrm{~b}$ \\
\hline & L1.2-P350-SH & $8.3 \pm 2.0 \mathrm{ab}$ & $0.81 \pm 0.29 \mathrm{ab}$ & $1.22 \pm 0.27 \mathrm{NS}$ & $88.6 \pm 14.9 \mathrm{~b}$ & $3.01 \pm 0.53 \mathrm{~b}$ \\
\hline \multirow[t]{6}{*}{ cv. Lvzhu } & F1.8-P250-SF & $8.6 \pm 2.0 \mathrm{~b}$ & $1.29 \pm 0.23 \mathrm{a}$ & $1.69 \pm 0.28 \mathrm{NS}$ & $118.2 \pm 16.8 \mathrm{a}$ & $4.54 \pm 0.55 \mathrm{a}$ \\
\hline & F1.8-P250-SH & $9.6 \pm 0.7 \mathrm{ab}$ & $0.83 \pm 0.12 \mathrm{~b}$ & $1.88 \pm 0.21 \mathrm{NS}$ & $90.2 \pm 10.3 \mathrm{c}$ & $3.31 \pm 0.56 \mathrm{c}$ \\
\hline & F1.8-P350-SH & $10.9 \pm 2.0 \mathrm{a}$ & $0.49 \pm 0.22 \mathrm{c}$ & $2.06 \pm 0.11 \mathrm{NS}$ & $111.6 \pm 11.8 \mathrm{ab}$ & $4.67 \pm 0.81 \mathrm{a}$ \\
\hline & L1.2-P250-SF & $8.1 \pm 2.4 \mathrm{~b}$ & $0.17 \pm 0.04 \mathrm{~d}$ & $1.83 \pm 0.24 \mathrm{NS}$ & $100.6 \pm 6.2 \mathrm{~b}$ & $3.93 \pm 0.37 \mathrm{~b}$ \\
\hline & L1.2-P250-SH & $6.6 \pm 1.7 \mathrm{c}$ & $0.47 \pm 0.10 \mathrm{c}$ & $1.95 \pm 0.61 \mathrm{NS}$ & $90.4 \pm 14.4 \mathrm{c}$ & $3.61 \pm 0.26 \mathrm{bc}$ \\
\hline & L1.2-P350-SH & $8.7 \pm 2.4 \mathrm{~b}$ & $0.67 \pm 0.09 \mathrm{bc}$ & $1.85 \pm 0.29 \mathrm{NS}$ & $112.9 \pm 8.2 \mathrm{ab}$ & $4.20 \pm 0.28 \mathrm{ab}$ \\
\hline \multirow[t]{6}{*}{ cv. Ziwei } & F1.8-P250-SF & $8.5 \pm 1.1 \mathrm{ab}$ & $0.78 \pm 0.29 \mathrm{~b}$ & $0.87 \pm 0.11 \mathrm{NS}$ & $90.9 \pm 21.7 \mathrm{ab}$ & $3.13 \pm 0.56 \mathrm{NS}$ \\
\hline & F1.8-P250-SH & $6.9 \pm 1.8 \mathrm{c}$ & $0.54 \pm 0.20 \mathrm{c}$ & $0.86 \pm 0.11 \mathrm{NS}$ & $90.7 \pm 21.3 \mathrm{ab}$ & $2.95 \pm 0.42 \mathrm{NS}$ \\
\hline & F1.8-P350-SH & $9.8 \pm 2.5 \mathrm{a}$ & $0.88 \pm 0.09 \mathrm{a}$ & $0.87 \pm 0.05 \mathrm{NS}$ & $97.7 \pm 22.5 \mathrm{a}$ & $3.05 \pm 0.58 \mathrm{NS}$ \\
\hline & L1.2-P250-SF & $7.5 \pm 1.7 \mathrm{~b}$ & $0.51 \pm 0.30 \mathrm{c}$ & $0.75 \pm 0.11 \mathrm{NS}$ & $79.8 \pm 4.3 \mathrm{~b}$ & $2.72 \pm 0.46 \mathrm{NS}$ \\
\hline & L1.2-P250-SH & $7.8 \pm 1.8 \mathrm{~b}$ & $0.82 \pm 0.25 \mathrm{ab}$ & $0.79 \pm 0.08 \mathrm{NS}$ & $73.3 \pm 7.4 \mathrm{c}$ & $2.66 \pm 0.16 \mathrm{NS}$ \\
\hline & L1.2-P350-SH & $9.9 \pm 1.0 \mathrm{a}$ & $0.57 \pm 0.14 \mathrm{c}$ & $0.87 \pm 0.14 \mathrm{NS}$ & $78.2 \pm 12.6 \mathrm{~b}$ & $3.05 \pm 0.47 \mathrm{NS}$ \\
\hline
\end{tabular}

\section{Conclusion}

To conclude, the results revealed that short-term exposure of lettuce varieties to half nitrogen supply and increased light intensity prior to harvest is suited to produce high quality lettuce with low nitrate content. This practice would be beneficial both for consumer and grower (low leaves nitrate content and high productivity). It's basically essential to understand cultivars response to light quality, light intensity and nitrogen fertilization in the closed plant factory system for effective lettuce quality control management. The functional efficiency of nutrients in plants depended on the light quality, light intensity, and ionic concentrations of nutrient solution. We purpose that more studies should be undertaken to optimize light quality with quantitative nutrient management to improve lettuce quality.

\section{References}

Abd-Elkader, D. Y., \& Alkharpotly, A. A. (2016). Effect of nitrogenous concentration solutions on vegetative growth, yield and chemical characters of celery (Apium Graveolens L). J. Plant Production, Mansoura Univ., 7(11), 1201-1206.

Ahmed, A. H. H., Khalil, M. K., \& Farrag, A. M. (2000). Nitrate accumulation, growth, yield and chemical composition of Rocket (Eruca vesicaria ssp. sativa) plant as affected by NPK fertilization, kinetin and salicylic acid. Proceedings of ICEHM 2000, Cairo University, Egypt (pp. 495-508).

Albornoz, F., \& Lieth, J. H. (2015). Over fertilization limits lettuce productivity because of osmotic stress. Chilean J. Agric. Res., 75, 284-290. https://doi.org/10.4067/S0718-58392015000400003

Albornoz, F., Lieth, J. H., \& Gonzalez-Fuentes, J. A. (2014). Effect of different day and night nutrient solution concentration on growth photosynthesis, and leaf $\mathrm{NO}_{3}{ }^{-}$content of aeroponically grown lettuce. Chilean J. Agric. Res., 74, 240-245. https://doi.org/10.4067/S0718-58392014000200017 
Aldesuquy, H. S., Abdel-Fattah, G. M., \& Baka, Z. A. (2000). Changes in chlorophyll, polyamines and chloroplast ultrastructure of Puccinia striiformis induced 'green islands' on detached leaves of Triticum aestivum. Plant Physiol. Biochem., 38, 613-620. https://doi.org/10.1016/S0981-9428(00)00783-X

Andersen, L., \& Nilesen, N. E. (1992). A new cultivation method for production of the vegetables with low content of nitrate. Sci. Hortic., 49, 167-171. https://doi.org/10.1016/0304-4238(92)90153-4

Anjana, S. U., Shahid, U., \& Muhammad, I. (2007). Nitrate accumulation in plants, factors affecting the process, and human health implications, a review. Agron. Sustain. Dev., 27, 45-57. https://doi.org/10.1051/ agro:2006021

Baslam, M., Pascual, I., Sanchez-Diaz, M., Erro, J., Garcia-Mina, J. M., \& Goicoechea, N. (2011). Improvement of nutritional quality of greenhouse-grown lettuce by arbuscular mycorrhizal fungi is conditioned by the source of phosphorus nutrition. J. Agric. Food Chem., 59(11), 129-140. https://doi.org/10.1021/jf202445y

Bian, Z. H., Yang, Q. C., \& Liu, W. K. (2015). Effects of light quality on the accumulation of phytochemicals in vegetables produced in controlled environments: A review. J. Sci. Food Agr., 95, 869-877. https://doi.org/ 10.1002/jsfa.6789

Borowski, E., Michałek, S., Rubinowska, K., Hawrylak-Nowak, B., \& Grudziński, W. (2014). The effects of light quality on photosynthetic parameters and yield of lettuce plants. Acta Sci. Pol. Hortorum Cultus, 14(5), 177-188.

Brady, N. C., \& Weil, R. R. (2008). Soil Colloids: Seat of soil chemical and physical acidity. In N. C. Brady, \& R. R. Weil (Eds.), The Nature and Properties of Soils (pp. 311-358). Pearson Education Inc.: Upper Saddle River, NJ, USA.

Branimir, U., Gvozden, D., Marija, R., \& Smiljana, G. B. (2017). The effect of N and NaCl on growth, yield, and nitrate content of salad rocket (Eruca Sativa Mill.). J. Plant Nutr., 40(18), 28-36.

Burns, I. G., Zhang, K., Turner, M. K., \& Edmondson, R. (2011). Iso-osmotic regulation nitrate accumulation in lettuce. J. Plant Nutr., 34, 283-313. https://doi.org/10.1080/01904167.2011.533328

Catherine, P. B., Lauren, C. B., Alex, H. L., Nicola, P. B., Natalie, C. W., Kevin, D. C., \& Jonathan, M. H. (2017). Vegetable-derived bioactive nitrate and cardiovascular health. Molecular Aspects of Medicine (pp. 1-9).

Chen, X. L., Guo, W. Z., Xue, X. Z., Wang, L. C., \& Qiao, X. J. (2014). Growth and quality responses of 'Green Oak Leaf' lettuce as affected by monochromic or mixed radiation provided by fluorescent lamp (FL) and light-emitting diode (LED). Sci. Hortic., 172, 168-175. https://doi.org/10.1016/j.scienta.2014.04.009

Chen, X. L., Yang, Q. C., Song, W. P., Wang, L. C., Guo, W. Z., \& Xue, X. Z. (2017). Growth and nutritional properties of lettuce affected by different alternating intervals of red and blue LED irradiation. Sci. Hortic., 223, 44-52. https://doi.org/10.1016/j.scienta.2017.04.037

Cometti, N. N., Martins, M. Q., Bremenkamp, C. A., \& Nunes, J. A. (2011). Nitrate concentration in lettuce leaves depending on photosynthetic photon flux and nitrate concentration in the nutrient solution. Hortic. Bras., 29, 548-553. https://doi.org/10.1590/S0102-05362011000400018

Demsar, J., Osvald, J., \& Vodnik, D. (2004). The effect of light-dependent application of nitrate on the growth of aeroponically grown lettuce (Lactuca sativa L.). J. Am. Soc. Hortic. Sci., 129, 570-575.

Du, S. T., Zhang, Y. S., \& Lin, X. Y. (2007). Accumulation of nitrate in vegetables and its possible implications to human health. Agricultural Sciences in China, 6(10), 1246-1255. https://doi.org/10.1016/S1671-2927 (07)60169-2

Emma, C., Youssef, R., Giancarlo, B., \& Stefania, D. P. (2016). Nutritional quality of ten leafy vegetables harvested at two light intensities. Food Chem., 199, 702-710. https://doi.org/10.1016/j.foodchem.2015. 12.068

Francisco, A., \& Heinrich, L. (2017). N, P, K and S uptake response to various levels of $\mathrm{CO}_{2}$ assimilation and growth rate in lettuce. J. Plant Nutr., 40(6), 773-783. https://doi.org/10.1080/01904167.2016. 1187745

Gartner, W. (2017). In-planta expression: Searching for the genuine chromophores of cryptochrome-3 from Arabidopsis thaliana. Photochem. Photobiol., 93(1), 382-384. https://doi.org/10.1111/php.12693

Gruda, N. (2005). Impact of environmental factors on product quality of greenhouse vegetables for fresh consumption. Crit. Rev. Plant Sci., 24, 227-247. https://doi.org/10.1080/07352680591008628 
Gunes, A., Post, W. H. K., Kirkby, E. A., \& Aktas, M. (1994). Influence of partial replacement of nitrate by amino acid nitrogen or urea in the nutrient medium on nitrate accumulation in NFT grown winter lettuce. $J$. Plant Nutr., 17, 1929-1939. https://doi.org/10.1080/01904169409364855

Hall, M. K. D., Jobling, J. J., \& Rogers, G. S. (2015). Effect of nitrogen supply and storage temperature on vitamin $\mathrm{C}$ in two species of baby leaf rocket, and the potential of these crops for a nutrient claim in Australia. J . Plant Nutr., 38(2), 246-259. https://doi.org/10.1080/01904167.2013.873465

Hernández, R., \& Kubota, C. (2016). Physiological responses of cucumber seedlings underdifferent blue and red photon flux ratios using LEDs. Environ. Exp. Bot., 121, 66-74. https://doi.org/10.1016/j.envexpbot.2015. 04.001

Hogewoning, S. W., Douwstra, P., Trouwborst, G., van Ieperen, W., \& Harbinson, J. (2010). An artificial solar spectrum substantially alters plant development compared with usual climate room irradiance spectra. $J$. Exp. Bot., 61, 1267-1276. https://doi.org/10.1093/jxb/erq005

Hung, H. C., Joshipura, K. J., Jiang, R., Hu, F. B., Hunter, D., Smith-Warner, S. A., ... Willett, W. C. (2004). Fruit and vegetable intake and risk of major chronic disease. J. Natl. Cancer Inst., 96(21), 577-1584. https://doi.org/10.1093/jnci/djh296

Izmailov, S. F. (2004). Saturation and utilization of nitrate pools in pea and sugar beet leaves. Russ. J. Plant Physl., 51, 189-193. https://doi.org/10.1023/B:RUPP.0000019212.20774.c7

Johkan, M., Shoji, K., Goto, F., Hashida, S., \& Yoshihara, T. (2010). Blue light-emitting diode light irradiation of seedlings improves seedling quality and growth after transplanting in red leaf lettuce. HortSci., 45, 1809-1814.

Kenny, O., \& Beirne, D. O. (2009). The effects of washing treatment on antioxidant retention in ready-to-use iceberg lettuce. Int. J. Food Sci. Technol., 44(6), 1146-1156. https://doi.org/10.1111/j.1365-2621.2009. 01935.x

Kim, H., Goins, G. D., Wheeler, R. M., \& Sager, J. C. (2004). Stomatal conductance of lettuce grown under or exposed to different light qualities. Annals Bot., 94, 691-697. https://doi.org/10.1093/aob/mch192

Konstantopoulou, E., Kapotis, G., Salachas, G., Petropoulos, S. A., Karapanos, I. C., \& Passam, H. C. (2010). Nutritional quality of greenhouse lettuce at harvest and after storage in relation to $\mathrm{N}$ application and cultivation season. Sci. Hort., 125(93), 91-95. https://doi.org/10.1016/j.scienta.2010.03.003

Kowalska, I. (1997). Effect of urea, ammonium, and nitrate nitrogen on the yield and quality of greenhouse lettuce grown on different media. Folia Hort., 9, 31-40.

Lee, S. K., \& Kader, A. A. (2000). Preharvest and postharvest factors influencing vitaminC content of horticultural crops. Postharvest Biol. Technol., 20, 207-220. https://doi.org/10.1016/S0925-5214(00) 00133-2

Lester, G. E. (2006). Environmental regulation of human health nutrients (ascorbic acid, carotene, and folic acid) in fruits and vegetables. HortScience., 41, 59-64.

Li, Q., \& Kubota, C. (2009). Effects of supplemental light quality on growth and phytochemicals of baby leaf lettuce. Environ. Expt. Bot., 67, 59-64. https://doi.org/10.1016/j.envexpbot.2009.06.011

Lillo, C. (1994). Light regulation of nitrate reductase in green leaves of higher plants. Phys. Plant, 90, 616-620. https://doi.org/10.1111/j.1399-3054.1994.tb08822.x

Lillo, C., \& Appenroth, K. J. (2001). Light regulation of nitrate reductase in higher plants: which photoreceptors are involved? Plant Biol., 3, 455-465. https://doi.org/10.1055/s-2001-17732

Liu, C. W., Sung, Y., Chen, B. C., \& Lai, H. Y. (2014). Effects of nitrogen fertilizers on the growth and nitrate content of lettuce (Lactuca sativa L). International Journal of Environmental Research \& Public Health, 11(4), 4427-4440. https://doi.org/10.3390/ijerph110404427

Liu, H., Fu, Y. M., Yu, J., \& Liu, H. (2016). Accumulation and primary metabolism of nitrate in lettuce (Lactuca Sativa L. Var. Youmaicai) grown under three different light sources. Communications in Soil Science and Plant Analysis, 47(17), 1994-2002. https://doi.org/10.1080/00103624.2016.1225076

Makus, D. J., \& Lester, G. (2002). Effect of soil type, light intensity, and cultivar on leaf nutrients in mustard greens. Subtrop. Plant Sci., 54, 23-28. 
Martinez-Luscher, J., Morales, F., Delrot, S., Sánchez-Díaz, M., Gomès, E., \& Aguirreolea, J. (2015). Climate change conditions (elevated $\mathrm{CO}_{2}$ and temperature) and UV-B radiation affect grapevine (Vitis vinifera cv. Tempranillo) leaf carbon assimilation, altering fruit ripening rates. Plant Sci., 236, 168-176. https://doi.org/10.1016/j.plantsci.2015.04.001

McCall, D., \& Willumsen, J. (1999). Effects of nitrogen availability and supplementary light on the nitrate content of soil-grown lettuce. J. Hort. Sci. Biotechnol., 74, 458-463. https://doi.org/10.1080/14620316.1999. 11511137

Mircea, D. C., Daniela-Lucia, M., Ibolya, F., \& Adriana, M. (2015). Growing patterns to produce 'nitrate-free' lettuce (Lactuca sativa L.). Food Additives \& Contaminants: Part A, 32(1), 80-86. https://doi.org/10.1080/ 19440049.2014.979887

Morris, M. C., Evans, D. A., Tangney, C. C., Bienias, J. L., \& Wilson, R. S. (2006). Associations of vegetable and fruit consumption with age-related cognitive change. Neurology, 67(8), 1370-1376. https://doi.org/ 10.1212/01.wnl.0000240224.38978.d8

Ombodi, A., Pesti, R., Balogh, A., Dimeny, J., Morikawa, C. K., \& Saigusa, M. (2010). Reducing nitrate accumulation of different vegetables by controlled-release fertilizer and chloride application. Acta Hortic., 938, 195-202.

Pavlos, T., Athanasios, K., \& Anastasios, S. S. (2014). Application of amino acids improves lettuce crop uniformity and inhibits nitrate accumulation induced by the supplemental inorganic nitrogen fertilization. Int. J. Agrig. \& Biology, 13(5), 951-955.

Pérez, L. U., Miranda, A. J., Mu, A., \& Mena, P. A. (2015). Interacting effects of high light and elevated CO2on the nutraceutical quality of two differently pigmented Lactuca sativa cultivars (Blonde of Paris Batavia and Oak Leaf). Sci. Hortic., 191, 38-48. https://doi.org/10.1016/j.scienta.2015.04.030

Qiu, W., Wang, Z., Huang, C., Chen, B., \& Yang, R. (2014). Nitrate accumulation in leafy vegetables and its relationship with water. J. Soil Sci. and Plant Nutr., 14(4), 761-168. https://doi.org/10.4067/S0718-9516 2014005000061

Rivas-Ubach, A., Sardans, J., Perez-Trujillo, M., Estiarte, M., \& Penuelas, J. (2012). Strong relationship between elemental stoichiometry and metabolome in plants. Proc. Natl. Acad. Sci., 109, 4181-4186. https://doi.org/ 10.1073/pnas.1116092109

Ryszard, K., Kazimierz, F., Justyna, S. G., Maria, G., Lorenza, T., Giovanni, A., \& Stanisław, K. (2017). Nutritive value of marketable heads and outer leaves of white head cabbage cultivated at different nitrogen rates. Acta Agriculturae Scandinavica, Section B-Soil \& Plant Science, 67(6), 524-533. https://doi.org/ 10.1080/09064710.2017.1308006

Santamaria, P. (2006). Nitrate in vegetables, toxicity content, intake and EC regulation. J. Sci. Food Agr., 86, 10-17. https://doi.org/10.1002/jsfa.2351

Santamaria, P., Elia, A., \& Gonnella, M. (1997). Changes in nitrate accumulation and growth of endive plants during light period as affected nitrogen level and form. J. Plant Nutr., 20, 1255-1266. https://doi.org/ $10.1080 / 01904169709365333$

Santamaria, P., Elia, A., \& Serio, F. (2001). Ways of reducing rocket salad nitrate content. Acta Hortic., 548, 529-537. https://doi.org/10.17660/ActaHortic.2001.548.64

Santiago, P., Diegoa, M., \& Cristina, G. (2008). Influence of light on health promoting phytochemicals of broccoli sprouts. J. Sci. Food Agric., 88, 904-910. https://doi.org/10.1002/jsfa.3169

Schonbeck, M. W., Rivera, R., O’Brien, J., Ebinger, S., \& Degregorio, R. E. (1991). Variety selection and cultural methods for lower initiate levels in winter greenhouse lettuce and endive. J. Sustainable Agr., 2, 49-75. https://doi.org/10.1300/J064v02n01_06

Seginer, I. (2003). A dynamic model for nitrogen-stressed lettuce. Ann. Bot., 91, 623-635. https://doi.org/ $10.1093 / \mathrm{aob} / \mathrm{mcg} 069$

Shen, G. M. (2016) Various Types of Nitrogen and Light Levels on Brassica chinensis yield and quality parameters under water stress. Communications in Soil Science and Plant Analysis, 47(15), 1721-1730.

Shohreh, V., \& Leila, M. (2015). Effect of some processing methods on nitrate changes in different vegetables. Food Measure, 9, 241-247. https://doi.org/10.1007/s11694-015-9229-4 
Siti, F. Y., Mahmud, T., Anwar, P., Siti, H. A., Farinazleen, M. G., \& Hamizah, H. (2015). Production system and harvesting stage influence on nitrate content and quality of butterhead lettuce. Bragantia, 74(3), 322-330. https://doi.org/10.1590/1678-4499.0453

Stagnari, F., Galieni, A., \& Pisante, M. (2015). Shading and nitrogen management affect quality, safety and yield of greenhouse-grown leaf lettuce. Sci. Hortic., 192, 70-79. https://doi.org/10.1016/j.scienta.2015.05.003

Wang, Z., Li, S., \& Malhi, S. (2008). Effects of fertilization and other agronomic measures on nutritional quality of crops. J. Sci. Food Agric., 88, 7-23. https://doi.org/10.1002/jsfa.3084

Wu, M. C., Hou, C. Y., Jiang, C. M., Wang, Y. T., Wang, C. Y., \& Chen, H. H. (2007). A novel approach of LED light radiation improves the antioxidant activity of pea seedlings. Food Chem., 101, 1753-1758. https://doi.org/10.1016/j.foodchem.2006.02.010

Yan, L., Zhang, Y. P., Liu, Z. H., Zhong, Z. W., \& Sun, M. (2014). Effects of nitrogen and calcium nutrition withdrawal before harvesting on biomass and nutritive and safety quality in spinach (Spinacia Oleracea L.). J. Plant Nutr., 37(14), 2270-2280. https://doi.org/10.1080/01904167.2014.920387

Yeh, N., \& Chung J.-P. (2009). High-brightness LEDs_-Energy-efficient lighting sources and their potential in indoor plant cultivation. Renew Sustain Energy Rev., 13, 2175-2180. https://doi.org/10.1016/j.rser.2009. 01.027

Zhang, G., Johkan, M., Hohjo, M., Tsukagoshi, S., \& Maruo, T. (2016). Plant growth and photosynthesis response to low potassium conditions in three lettuce (Lactuca sativa) types. Hortic. J., 86(2), 1-7.

Zhou, W. L., Liu, W. K., \& Yang, Q. C. (2013). Reducing nitrate content in lettuce by pre-harvest continuous light delivered by red and blue light-emitting diodes. J. Plant Nutr., 36, 481-490. https://doi.org/10.1080/ 01904167.2012.748069

\section{Copyrights}

Copyright for this article is retained by the author(s), with first publication rights granted to the journal.

This is an open-access article distributed under the terms and conditions of the Creative Commons Attribution license (http://creativecommons.org/licenses/by/4.0/). 